\title{
Pelatihan Pendesainan Spanduk dengan Memanfaatkan Software CorelDraw sebagai Bekal Berwirausaha bagi Pemuda Karang Taruna Se-Kecamatan Gondang
}

\author{
Hanim Faizah \\ Universitas PGRI Adi Buana Surabaya
}

\author{
Nur Fathonah \\ Universitas PGRI Adi Buana Surabaya
}

\begin{abstract}
Youth in Gondang Sub-District of Mojokerto Regency still work in agriculture and factories. Many of them want to be entrepreneurs, but do not yet have other skills. Therefore, they need to be equipped with the ability in entrepreneurship, i.e. the ability in graphic design. Based on the observations, it is known that the skills and understanding of youth in this region are still less related to CorelDraw's usage. The solution offered is the implementation of training in designing banners with CorelDraw software for youth in the District of Gondang, Mojokerto. The results obtained from this activity are the increase in the soft skills of youth in the District of Gondang in increasing economic independence. The soft skills increased are influenced by the use of CorelDraw software in designing the banners.
\end{abstract}

Keywords: Banner design; Youth Mojokerto; Design graphic workshop; Soft skill development

\section{Abstrak}

Pemuda di Kecamatan Gondang, Kabupaten Mojokerto masih bekerja di bidang pertanian dan pabrik. Kebanyakan mereka ingin berwirausaha. Namun, mereka belum memiiki keahlian lain. Oleh karena itu, mereka perlu dibekali dengan kemampuan dalam berwirausaha, salah satunya adalah kemampuan dalam desain grafis. Berdasarkan hasil observasi, diketahui bahwa keterampilan dan pemahaman pemuda karang taruna di wilayah tersebut masih kurang dalam hal penggunaan CorelDraw untuk proses desain spanduk. Solusi yang ditawarkan adalah dilaksanakannya pelatihan dalam pendesainan spanduk dengan software CorelDraw bagi Pemuda seKecamatan Gondang, Mojokerto. Hasil yang diperoleh dari kegiatan ini adalah peningkatan soft skill pemuda karang taruna di Kecamatan Gondang dalam meningkatkan kemandirian ekonomi. Salah satu soft skill tersebut adalah hasil pemanfaatan software CorelDraw untuk mendesain spanduk.

Kata kunci: Desain spanduk; Karang taruna Mojokerto; Pelatihan desain grafis; Peningkatan soft skill

\section{Pendahuluan}

Karang taruna adalah organisasi sosial kemasyarakatan sebagai wadah dan sarana pengembangan setiap anggota masyarakat yang tumbuh dan berkembang atas dasar kesadaran dan tanggung jawab sosial dari, oleh, dan untuk masyarakat terutama generasi muda di wilayah desa/kelurahan, terutama bergerak di bidang usaha kesejahteraan sosial (Kemensos, 2010). Sebagai contoh, karang taruna di Kecamatan Gondang. Karang taruna yang terletak di kabupaten Mojokerto ini masih banyak yang menganggur atau belum bisa mendapatkan penghasilan karena masih kurangnya keterampilan yang dimiliki.

Dalam perkembangan teknologi yang sangat pesat ini, untuk memperoleh penghasilan tidak harus dengan bekerja pada suatu perusahaan, tetapi juga dapat diperoleh dari kegiatan wirausaha (Tjahjono \& Palupi, 2014). Wirausaha yang akan dikembangkan bisa dituangkan dalam bidang yang bermacam-macam, salah satunya adalah bidang usaha yang berkaitan dengan multimedia dan desain grafis. Pemanfaatan multimedia sangatlah banyak, di antaranya untuk: 
media pembelajaran, game, film, medis, militer, bisnis, desain, arsitektur, olahraga, hobi, iklan/promosi, dan lain-lain (Wahono dalam Nining, 2007).

Desain grafis sangat bermanfaat bagi masyarakat saat ini, disesuaikan dengan perkembangan teknologi yang semakin pesat. Hal ini dapat dilihat dari perkembangan dunia bisnis atau perdagangan yang sangat mengedepankan tampilan gambar dalam bentuk banner atau spanduk yang dapat membantu para pengusaha dalam memasarkan barang dagangannya. Desain Grafis umumnya diterapkan dalam dunia periklanan packaging, perfilman, dan lain-lain (Riyanto, 2006). Selain itu, kegiatan karang taruna sendiri juga sangat membutuhkan backdrop yang akan memperjelas kegiatan yang sedang dilakukan.

Desain grafis adalah salah satu bentuk seni terapan yang memberi kebebasan dan keleluasaan kepada desainer untuk memilih, menciptakan, dan mengatur elemen rupa seperti ilustrasi, foto, tulisan, dan garis di atas permukaan kanvas atau area kerja dengan tujuan untuk diproduksi dan dikomunikasikan sebagai sebuah pesan. Dalam desain grafis, diterapkan elemenelemen dan prinsip-prinsip desain (komposisi) dalam memproduksi sebuah karya visual (Sitepu, 2006).

Dengan menguasai berbagai software desain grafis, diharapkan pengguna akan dapat mengedit foto secara sederhana dan mengaplikasikannya dalam berbagai bentuk publikasi cetak seperti logo, pamflet, brosur, kartu nama, poster, buku, tata letak/layout majalah, desain iklan, undangan, sampul majalah, dan lain sebagainya. Software desain grafis paling populer yang dapat dimanfaatkan yaitu Adobe Photoshop dan CorelDraw. Menurut Hidayat (2011), Adobe Photoshop, atau biasa disebut Photoshop, adalah perangkat lunak editor citra buatan Adobe Systems yang dikhususkan untuk pengeditan foto/gambar dan pembuatan efek.

Selain software Adobe Photoshop, software lain yang tidak kalah populer adalah CorelDraw. CorelDraw adalah software pengolah gambar vektor, bisa dikatakan software untuk membuat gambar vektor. Software ini merupakan salah satu produk dari Corel Corporation, perusahaan pembuat software komputer yang didirikan pada tahun 1985 di Ottawa, Kanada (Arum, 2017). Secara umum, fungsi CorelDraw adalah sebagai editor grafik vektor yang menghasilkan gambar visual. Namun, banyak sekali pengguna CorelDraw yang memiliki insting desain grafis atau karya visual yang menggunakannya di berbagai bidang. CorelDraw sangat laris di pasaran dan banyak digunakan untuk membuat desain grafis yang bagus.

Namun, dari hasil observasi, diketahui bahwa keterampilan dan pemahaman karang taruna di Kecamatan Gondang, Kabupaten Mojokerto ini masih kurang terkait dengan teori penggunaan CorelDraw. Hal ini karena para anggota karang taruna jarang mengikuti pelatihanpelatihan yang mengarahkan mereka pada pengetahuan luas berkenaan dengan pendesainan spanduk dengan menggunakan CorelDraw. Karang taruna berangggotakan pemuda dan pemudi (dalam AD/ART-nya, diatur keanggotaanya mulai usia 11-40 tahun) dan batas sebagai pengurus adalah berusia 17-35 tahun.

Berdasarkan hasil wawancara langsung dengan ketua pengurus karang taruna sekecamatan Gondang dan hasil survei lapangan dengan mencermati kondisi yang ada, bahwa banyak anggota karang taruna di wilayah Kecamatan Gondang, Mojokerto yang sangat kurang dalam memahami akan pentingnya penggunaan CorelDraw. Padahal, pemahaman tersebut sangat penting untuk bekal mereka dalam berwirausaha guna menambah penghasilan. Dengan demikian, berdasarkan hasil wawancara dengan Ketua Pengurus Karang Taruna di sana, diperlukan suatu pelatihan yang dapat mengatasi masalah tersebut.

Oleh sebab itu, solusi yang akan ditawarkan yaitu suatu program yang bisa meningkatkan keterampilan karang taruna melalui pengenalan desain spanduk berbantuan software CorelDraw yaitu berupa Pelatihan Pendesainan Spanduk dengan Memanfaatkan Software CorelDraw. 


\section{Metode Pelaksanaan}

Ada empat tahap dalam kegiatan pengabdian kepada masyarakat (PPM) ini. Empat tahap itu adalah sebagai berikut.

1) Tahap Perencanaan

Pada tahap perencanaan, langkah kegiatan yang dilakukan yaitu:

a) merumuskan tujuan dan tema kegiatan,

b) menganalisis kebutuhan mitra, dan

c) merancang bahan presentasi CorelDraw.

2) Tahap Sosialisasi

Pada tahap ini, diadakan pelatihan pendesainan spanduk dengan memanfaatkan software CorelDraw.

3) Tahap Laporan

4) Tahap Tindak Lanjut

Secara skematis, metode pelaksanaan digambarkan dalam Gambar 1.

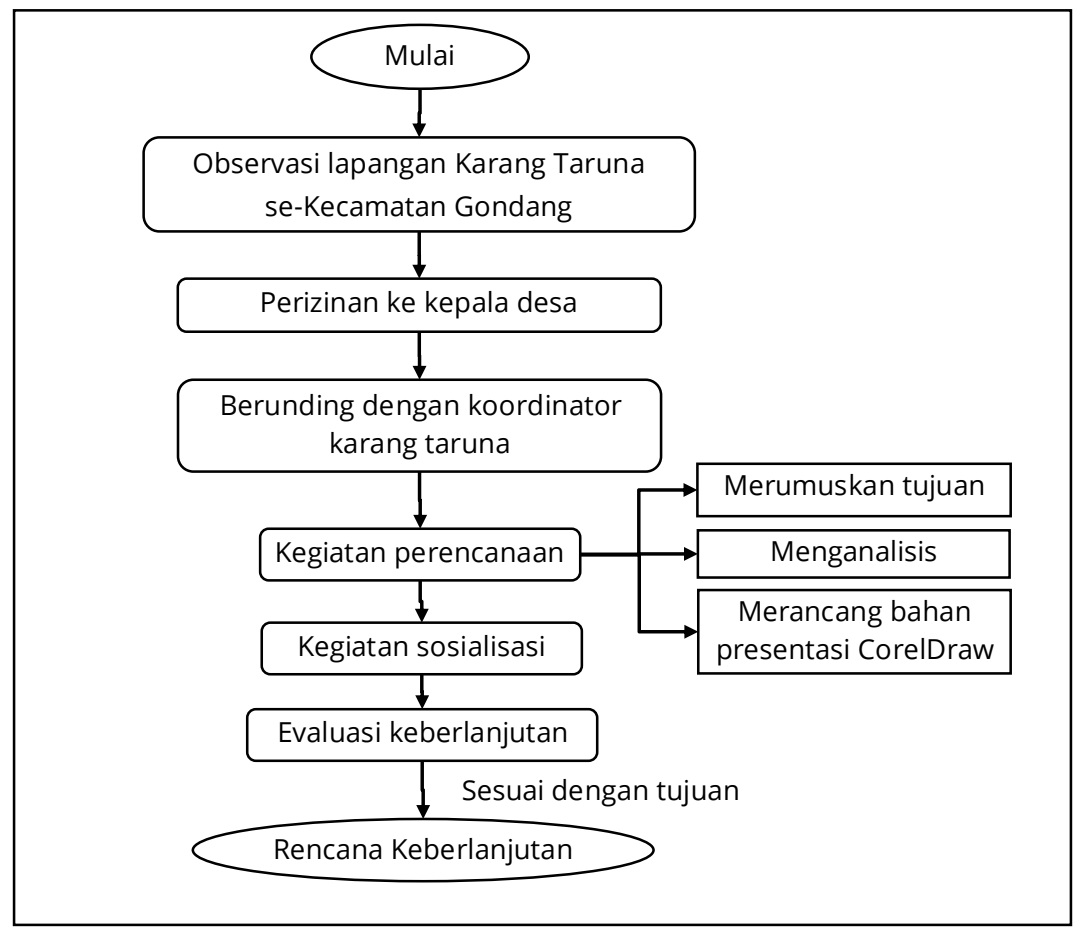

Gambar 1. Alur Kegiatan PPM

\section{Hasil dan Pembahasan}

Kegiatan PPM ini telah berhasil dilaksanakan oleh Tim Program Studi Pendidikan Matematika, Fakultas Keguruan dan Ilmu Pendidikan, Universitas PGRI Adi Buana Surabaya yang bekerja sama dengan karang taruna se-Kecamatan Gondang. PPM ini dihadiri oleh 30 orang anggota karang taruna perwakilan masing-masing desa di Kecamatan Gondang. Pelaksanaan PPM ini bertempat di Kantor Kecamatan Gondang, Jalan Raya Gondang-Pacet No. 9, Gondang, Kabupaten Mojokerto. Proses pelaksanaan kegiatan PPM ini terlaksana dalam beberapa tahapan sebagai berikut. 
1) Tahap Persiapan

Kegiatan yang dilakukan pada tahap persiapan di antaranya:

a) Tahapan Koordinasi Pertama

Koordinasi persiapan kegiatan PPM ini diawali dengan membentuk panitia pada tanggal 14 Januari 2019 melalui rapat program studi. Ada beberapa saran dari panitia mengenai tema PPM yang didasarkan pada berbagai masalah yang dihadapi oleh warga di Kecamatan Gondang. Masalah-masalah yang dihadapi oleh warga dikumpulkan oleh para dosen dan dibantu oleh mahasiswa di Program Studi Pendidikan Matematika selama satu bulan, bersamaan dengan dilaksanakannya kegiatan KKN (kuliah kerja nyata) di Kecamatan Gondang. Kemudian, berdasarkan musyawarah bersama, diputuskan tema PPM yaitu Pelatihan Pendesainan Spanduk dengan Software CorelDraw sebagai Bekal Berwirausaha bagi Pemuda Karang Taruna Se-Kecamatan Gondang.

\section{b) Tahapan Koordinasi Kedua}

Panitia PPM melakukan koordinasi dengan pihak Kecamatan Gondang, Mojokerto, di antaranya mengenai tema, tempat, waktu pelaksanaan, sarana-prasarana yang dibutuhkan, dan sasaran peserta yang akan diikutsertakan. Koordinasi dengan pihak Kecamatan Gondang ini dilakukan pada tanggal 28 Januari 2019. Hasil koordinasi ini berupa izin pelaksanaan, penetapan tempat dan waktu pelaksanaan, sarana dan prasarana yang dibutuhkan, sasaran peserta yang diundang, serta prosedur undangan untuk peserta.

\section{c) Tahapan Koordinasi Ketiga}

Panitia melakukan diskusi dengan pihak di Kecamatan Gondang untuk menetapkan materi apa yang dibutuhkan oleh karang taruna se-Kecamatan Gondang untuk disampaikan pada saat pelaksanaan kegiatan PPM yang sesuai dengan kebutuhan karang taruna di Kecamatan Gondang.

\section{d) Tahapan Koordinasi Keempat}

Berdasarkan hasil diskusi, disusun materi yang akan disampaikan pada kegiatan PPM. Setelah materi ditetapkan pada tanggal 31 Januari 2019, diadakan rapat koordinasi panitia untuk menentukan pembagian materi bagi narasumber.

\section{e) Tahapan Koordinasi Kelima}

Pemateri melakukan simulasi mengenai materi yang akan dipresentasikan pada tanggal 13 Februari 2019 di ruang laboatorium komputer program studi Pendidikan Matematika, Universitas PGRI Adi Buana Surabaya. Sementara, panitia lainnya melakukan koordinasi terakhir terkait susunan acara, format sertifikat, dan hal-hal lainnya.

\section{2) Tahapan Pelaksanaan}

Rincian kegiatan pelaksanaan PPM dapat dilihat pada Tabel 1. Secara umum, pelaksanaan pelatihan di Kecamatan Gondang diikuti peserta dengan penuh antusias. Pada awal pelatihan, peserta masih awam dengan software CorelDraw sehingga pelatihan diawali dengan penyampaian materi tentang gambaran secara umum tentang software CorelDraw. Kemudian, dilanjutkan dengan peserta diminta untuk memasang software CorelDraw di laptop masing-masing dengan dibantu oleh panitia. Selanjutnya, peserta diberikan pelatihan untuk membuat spanduk, dimulai dari desain yang paling sederhana hingga yang kompleks.

Dari kegiatan ini, para peserta merasa sangat beruntung karena telah mengikuti pelatihan ini. Peserta merasa kemampuan yang diperoleh sangat diperlukan, baik untuk membuka peluang usaha baru maupun untuk keperluan dalam kegiatan sehari-hari karang taruna mengingat dalam kegiatan karang taruna selalu dibutuhkan spanduk ataupun backdrop untuk mendukung acara. Sebelumnya, untuk membuat spanduk dan backdrop di setiap acara, para pemuda karang taruna harus memesan dari pihak di luar karang taruna 
ataupun membuat semampu mereka dan masih kurang menarik. Namun, setelah mengikuti pelatihan ini, mereka berusaha membuat sendiri berbekal kemampuan yang diperoleh pada pelatihan yang telah dilaksanakan.

Tabel 1. Hasil Pelaksanaan Kegiatan Pelatihan

\begin{tabular}{|c|c|c|c|c|}
\hline No. & Nama Kegiatan & Subkegiatan & $\begin{array}{l}\text { Waktu } \\
\text { Pelaksanaan }\end{array}$ & Keterangan \\
\hline 1 & $\begin{array}{l}\text { Sosialisasi materi } \\
\text { bagi peserta } \\
\text { tentang Desain } \\
\text { Grafis }\end{array}$ & $\begin{array}{l}\text { Penyampaian } \\
\text { materi mengenai } \\
\text { lingkup teori } \\
\text { Desain Grafis }\end{array}$ & $\begin{array}{l}25 \text { Februari } 2019 \\
\text { Pukul 11.00-12.30 }\end{array}$ & $\begin{array}{l}\text { Peserta yang } \\
\text { sangat antusias } \\
\text { untuk mengikuti } \\
\text { pelatihan yang } \\
\text { akan datang }\end{array}$ \\
\hline 2 & $\begin{array}{l}\text { Sosialisasi materi } \\
\text { bagi karang taruna } \\
\text { di Kecamatan } \\
\text { Gondang tentang } \\
\text { Desain Grafis }\end{array}$ & $\begin{array}{l}\text { Penyampaian } \\
\text { materi tentang } \\
\text { pendesainan } \\
\text { spanduk dengan } \\
\text { memanfaatkan } \\
\text { software } \\
\text { CorelDraw yang } \\
\text { dapat diterapkan } \\
\text { di desa masing- } \\
\text { masing }\end{array}$ & $\begin{array}{l}\text { 11 Maret } 2019 \\
\text { Pukul 12.00-13.30 }\end{array}$ & $\begin{array}{l}\text { - Pada pertemuan } \\
\text { kedua ini, } \\
\text { peserta } \\
\text { pelatihan dapat } \\
\text { mengikuti } \\
\text { pelatihan } \\
\text { dengan media } \\
\text { yang memadai. } \\
\text { - Pada pertemuan } \\
\text { ini, beberapa } \\
\text { peserta belum } \\
\text { memiliki media } \\
\text { laptop untuk } \\
\text { secara langsung } \\
\text { mempraktikkan } \\
\text { materi. }\end{array}$ \\
\hline 3 & $\begin{array}{l}\text { Pelatihan bagi } \\
\text { karang taruna di } \\
\text { Kecamatan } \\
\text { Gondang tentang } \\
\text { Pendesainan } \\
\text { Spanduk dengan } \\
\text { Memanfaatkan } \\
\text { Software } \\
\text { CorelDraw }\end{array}$ & $\begin{array}{l}\text { Praktik oleh } \\
\text { peserta mengenai } \\
\text { Pendesainan } \\
\text { Spanduk dengan } \\
\text { Memanfaatkan } \\
\text { Software } \\
\text { CorelDraw }\end{array}$ & $\begin{array}{l}23 \text { Maret } 2019 \\
\text { Pukul 08.00-14.00 }\end{array}$ & $\begin{array}{l}\text { Peserta antusias } \\
\text { mengikuti } \\
\text { pelatihan, } \\
\text { meskipun } \\
\text { beberapa peserta } \\
\text { masih perlu } \\
\text { pendampingan } \\
\text { secara intensif. }\end{array}$ \\
\hline 4 & $\begin{array}{l}\text { Pelatihan bagi } \\
\text { karang taruna di } \\
\text { Kecamatan } \\
\text { Gondang dalam } \\
\text { memanfaatkan } \\
\text { Software } \\
\text { CorelDraw }\end{array}$ & $\begin{array}{l}\text { Praktik oleh } \\
\text { peserta mengenai } \\
\text { pendesainan } \\
\text { spanduk dengan } \\
\text { software } \\
\text { CorelDraw }\end{array}$ & $\begin{array}{l}29 \text { Maret } 2019 \\
\text { Pukul 08.00-12.00 }\end{array}$ & $\begin{array}{l}\text { Peserta mengikuti } \\
\text { dengan baik } \\
\text { hingga dihasilkan } \\
\text { satu produk dari } \\
\text { beberapa kali } \\
\text { kegiatan. }\end{array}$ \\
\hline
\end{tabular}


Gambar 2 mengilustrasikan salah satu hasil kerja peserta kegiatan pelatihan.

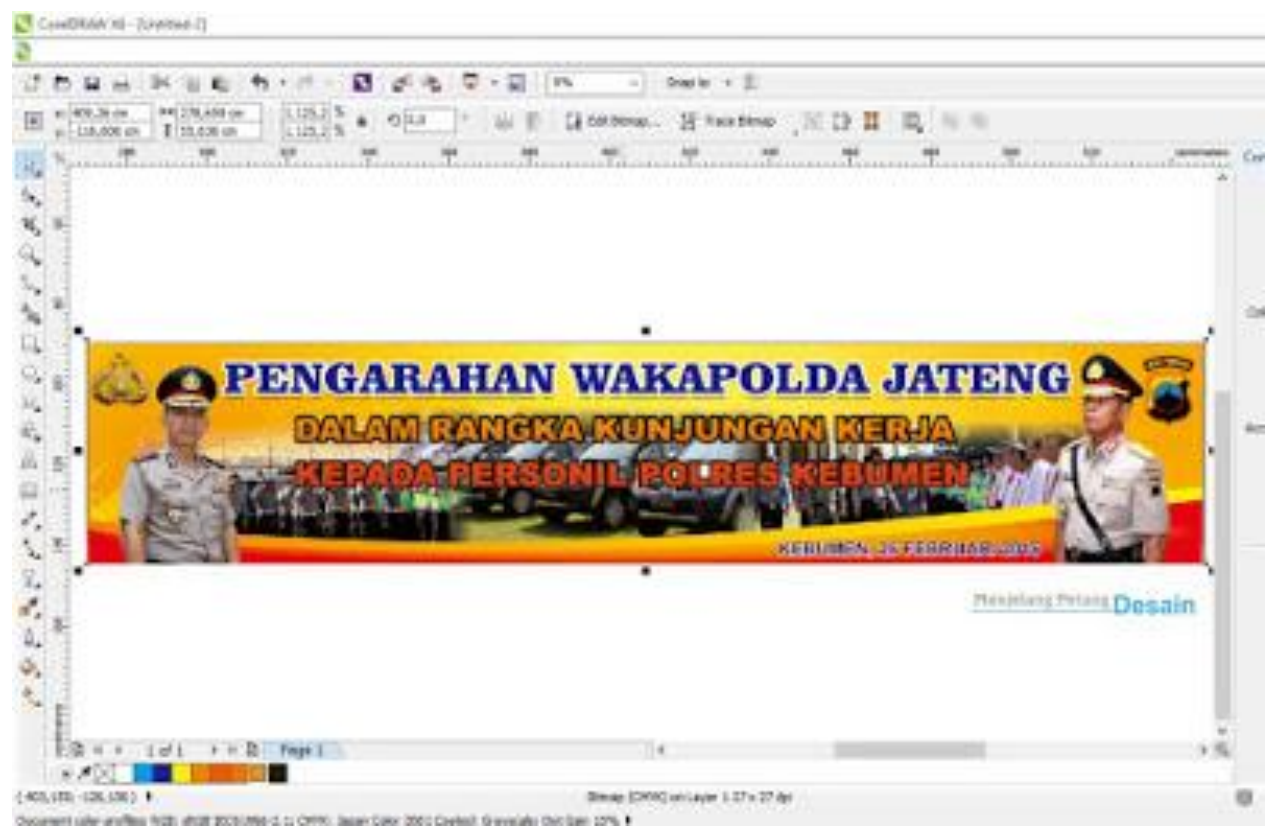

Gambar 2. Spanduk Hasil Kerja Peserta Pelatihan dalam Bentuk Soft File

Pelaksanaan pelatihan dapat diamati dalam dokumentasi pada Gambar 3 dan 4 .
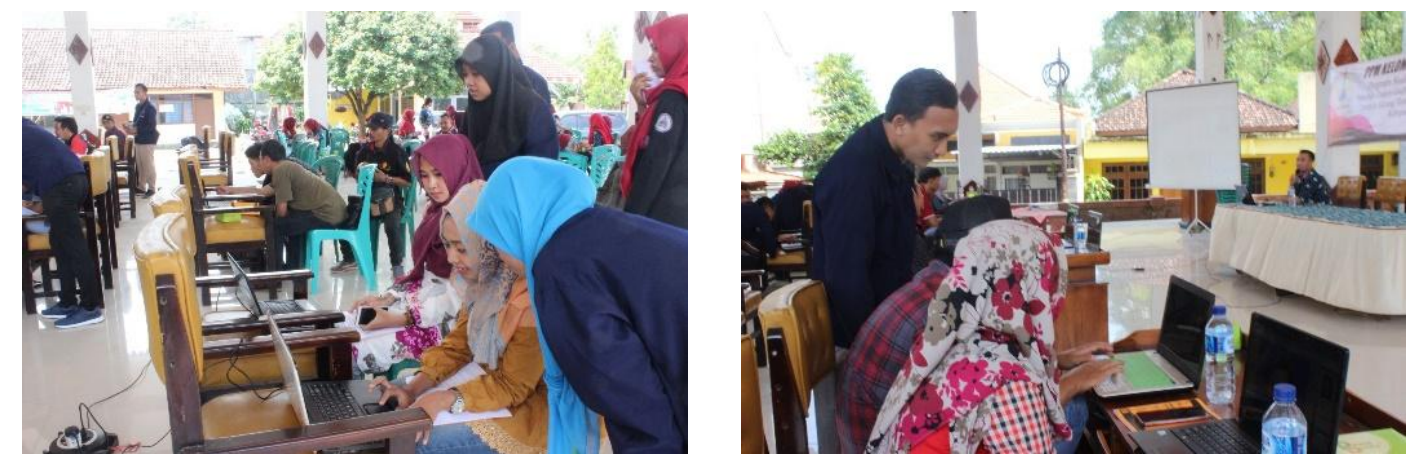

Gambar 3. Peserta Dibantu Panitia dalam Pelatihan
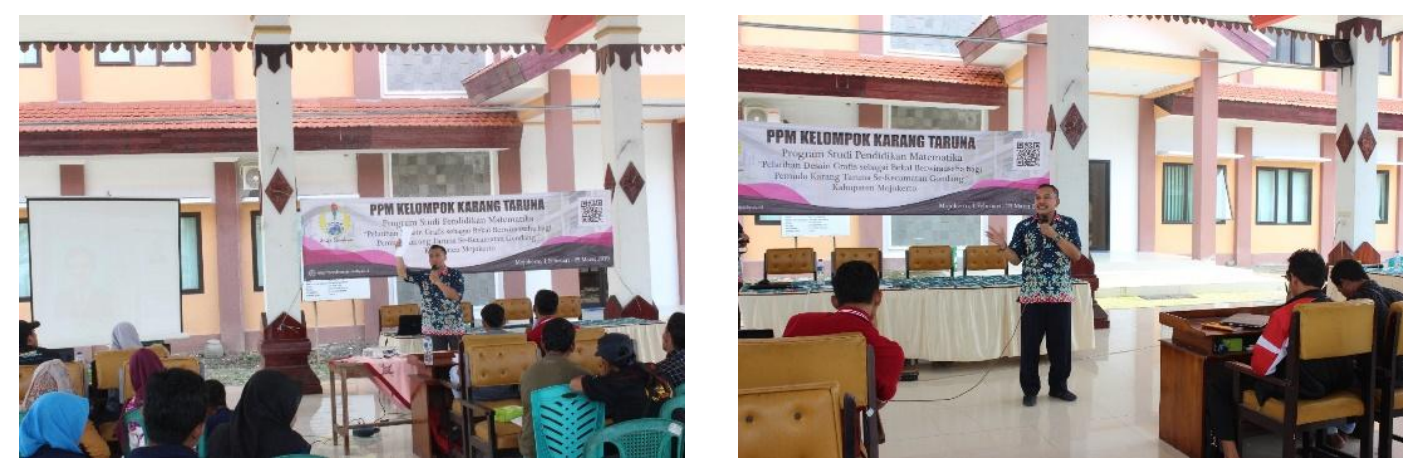

Gambar 4. Narasumber 1 Pelatihan sedang Menyampaikan Materi 


\section{Kesimpulan}

Kesimpulan yang dapat ditarik adalah dengan dilakasakannya pelatihan yang dapat meningkatkan soft skill, pemuda karang taruna di Kecamatan Gondang dapat meningkatkan motivasi generasi muda karang taruna agar lebih dapat berkreasi serta dapat meningkatkan kemandirian ekonomi bagi seluruh pemuda di Kecamatan Gondang. Setelah terlaksananya kegiatan ini, karang taruna dapat mengembangkan jiwa wirausaha melalui keterampilan dalam mendesain spanduk dengan memanfaatkan software CorelDraw.

\section{Ucapan Terima Kasih}

Terselenggaranya kegiatan pelatihan ini tidak terlepas dari kerja sama yang baik antara Tim Dosen Matematika, pihak Kecamatan Gondang, Mojokerto, dan Pengurus Karang Taruna seKecamatan Gondang. Oleh karena itu, penulis mengucapkan terima kasih kepada seluruh pihak terkait. Selain itu, ucapan terima kasih juga disampaikan kepada pihak internal LPPM Universitas PGRI Adi Buana Surabaya atas pendanaan yang telah diberikan untuk kesuksesan pelaksanaan kegiatan Pelatihan Pendesainan Spanduk dengan Memanfaatkan Software CorelDraw.

\section{Daftar Pustaka}

Arum, D. (2017). Sejarah dan Perkembangan CorelDRAW. Diambil dari http://ilmuti.org/wpcontent/uploads/2017/05/Diah-Arum-SEJARAH-DAN-PERKEMBANGAN-CORELDRAW.pdf

Hidayat, H. (2011). Menjadi Master Photoshop untuk Pemuia dari Nol Hingga Mahir. Jakarta: Dunia Komputer.

Kemensos. Peraturan Menteri Sosial Republik Indonesia Nomor: 77/HUK/2010 Tentang Pedoman Dasar Karang Taruna. , (2010).

Nining. (2012). Pengertian Multimedia Interaktif. Diambil dari http://nining.dosen.narotama .ac.id/2012/02/06/pengertian-multimedia-interaktif

Riyanto, S. (2006). Bagaimana memulai belajar Desain Grafis? Diambil dari https://ilmukomputer .org/2006/12/27/bagaimana-memulai-belajar-desain-grafis/

Sitepu, V. (2006). Panduan Mengenal Desain Grafis. Diambil dari http://www.belajargrafis .imywebsit

Tjahjono, H. K., \& Palupi, M. (2014). Model konseptual intensi berwirausaha berbasis teknologi informasi (ti). Jurnal Bisnis: Teori dan Implementasi, 5(1), 1-10. 


\section{Afiliasi:}

Hanim Faizah*, Nur Fathonah

Program Studi Pendidikan Matematika, Universitas PGRI Adi Buana Surabaya

Jl. Ngagel Dadi III B/37, Surabaya, Jawa Timur

E-mail : fhanim@unipasby.ac.id*,nurfathonah@unipasby.ac.id 